\title{
Anxiety of Influence
}

\author{
Sharron Margaret Turner
}

\section{L'Influence, l'angoisse}

Des poèmes en prose: dix esquisses où proliferent des images de la peur, de l'impuissance infligée aux écrivaines désirantes par l'institution littéraire et son panthéon masculine. L'exemple de Virginia Woolfsuicidée. Les dictionnaires, les encyclopédies, les journaux (National Enquirer), la Bible (Génésis) les textes du droit (The Law of Civil Procedure) regorgent des récits, des lois, qui tracent l'image de la femmeanimale, de la femme-cheval - la viande ou la merde ("horse"I"whores" [putains])-fouettée par les hommes. Une blessure dans les côtes d'Adam pour devenir sa viande? Contre cet abaissement s'insurgent Olympe de Gouges avec la déclaration des droits de la femme et les poètes sapphiques avec leurs ry thmes flambés pour rendre malade l'armée des hommes. 
inferiorization. that's us. the female. afraid to yell. afraid to hurt the men for fear. for fear of what? of being accused of being over-sensitive to our past. by them. men. what past? o.k. our present. present yourself as preferably blond, beautiful, slender, senseless, and above all, ageless. an arm piece, please. no wit unless it rhymes with tit. tits and ass. for fear of being left. fear of being beaten. to death. cold in the night. fe male. wo man. suffix to male. men. horseshit.

the luck is in the referent. the $\mathrm{h}-\mathrm{o}-\mathrm{r}-\mathrm{s}-\mathrm{e}$. the thing that kicks. the bite is worse. I had a dream once where I was forced to eat my own flesh. flashed a toothy grin at sigmund. he's dead too though I read somewhere where he died grinning. grinning and holding a hardon. his. his fingers had to be broken in order to pry them off. his penis too. had to be broken. kafka's dead too. he was impotent. too bad he hated his dad so much. hated brothels and lentil soup too. 
kafkaesque: one should not hate men. one should hate, instead, the patriarchy, who rules the collective spirituality of the human race.

pure reason: if one puts a square peg into a round hole, what's left is yellow. a red rose. a wound. in adam's rib.

front page of the national enquirer: woman born from man's rib. for his meat: genesis 1:29.

29 is the end of the line for woman. old, sweety. old women don't get hired. don't tell their age. tummy tucks and thigh sucks. hence, there are few old women in history. ann boleyn. 1507-1536. 29. beheaded. born with an extra finger, though, an extra appendage with which to eat cake instead of milk. 1789. mademoiselle olympe de gouges. proposed a "declaration of the rights of women" equivalent to the "declaration of the rights of men." proposed all masculine privilege be abolished. her proposal: burned. she: guillotined. this is an old and tendentiously malecentered story. kicked by a dead horse. 
3.

venus of willendorf. c. $25,000-20,000$ b.c. stone. $43 / 8^{\prime \prime}$ high. naturhistorisches museum, vienna.

c. 1,990 a.d. just a little over 29. so it is that woman has come a long way in the past thirty years. take her latest and greatest virgin mother, teresa. divinely aspired. sir margaret thatcher. loyal venus who right wings her common sot. with love. I love lucy. on valium. mrs. bill cosby. and so on. so the foreleg of a horse is homologue to the right wing of a bird.

so the penis, the organ with which male animals copulate, is homologue to the clitoris, a small erectile organ at the upper part of the vulva. the organ with which female animals await the verb which links. as the verb at montréal island, canada, c.1,989 a.d. just a little ill-humoured horseplay. the end of a triptych. 


$$
\begin{aligned}
\text { oedipus complex: } & \text { electra complex: } \\
\text { strong } & \text { compulsive } \\
\text { typically unconscious } & \text { strongly repressed } \\
\text { attachment } & \text { sexual attachment } \\
\text { son to mother } & \text { daughter to father. }
\end{aligned}
$$

it is utterly natural for little boys to sexualize mother. this is clear as defined above in funk \& wagnalls. and we are all secure in our knowledge that dictionaries are reliable, non-sexist, referential sources. therein, language is semanticized. history, too, provides sophisticated evidence that to sexualize mother is to fulfil the wish of boyhood. in fact, it may well be that boys are all destined to direct their first sexual impulses toward their mothers. one of our ancient friends puts it well:

for many a man hath seen himself in dream his mother's mate, but he who gives no heed to suchlike matters bears the easier life. horsesense.

whinny whinny neigh neigh. née feminine. chattering, canting cunts. always trying to stir up shit. godda put'em in their place every once in a while. keep 'em in line. like that three year old bitch in vancouver. sexually aggressive. judge said so himself. said she asked for it. deserved it. oughtta be horsewhipped. hell, them witches don't need to see no penis to envy one. it's in their blood. says so right up there in funk \& wagnalls. plain and simple. 
5.

hey, sigmund got it from the greeks: pure reason. so it was that jocasta's first born son inadvertently mounted the prize of his estranged mother's ass. sired several. that's what they say. quite simply, jocasta was ordered by her owner-murdered-husband's-brother-or-son, to stick her ass in the air just so. as with the custom of the day. to ensure the sexual arousal of her new husband. oedipus. so it is that calgary's local son inadvertently mounted the prize of his estranged wife's ass. spurred several.

bubble bubble toil and plough. richwitch. electra. helped her brother murder mother who murdered father too. stuck her ass in the air for no man. it therefore follows that all females fantasize rape. compulsively. especially little girls. by their fathers. dime-sized snatches have that touch of je ne sais quoi for the mature erect penis. tight squeeze. little girls love it. a horse's ass. 
6.

man has trotted such a long and arduous trek over the past 30,000 years. primitive masculine fearlessness is much greater than 4 . in the same rein of symbolic logic, man has invented rule, a form of control or power. for example, a simple rule: $\operatorname{man}=$ man \& woman \& girl \& boy; whereas woman $=$ woman . girl $=$ girl. and so on. some rules are made into laws. by judges. revered men in world politics. benevolence begotten by god. stacks of books, written primarily for students of law, describe these men best. just so:

1 williston \& rolls. in the law of civil procedure. preface. vol. 1. 1970:

it is a must that students of law acquaint themselves with the lore, integrity, and beautiful use of the english language which is to be found in the writings of our judges. it is a must that students of the law focus their attention not only on the rationale of the cases but also on the precise language which the judges have used in deciding them; so much in law depends on the niceties of expression.

2 a canadian judge. in the globe and mail. front page. 1990: rules are like women. they are made to be violated. horseshit on the road. exactly. 
case no. 1. primitive masculine fearfulness is no less than one in 29 human beings. the white male man. from the horse's mouth.

case no. 2. women are nothing like horses. or 4 wheel drives. sure, some like to eat apples, but generally, women won't want to move. even man and his gods cannot prod her. whips, fists, boots, bile. still: stuck. still. skirt, pussy, piece.horsebreath. 


\title{
$40 \cdot$ Tessera
}

8.

the luck is in the referent. the $\mathrm{h}-\mathrm{o}-\mathrm{u}$ - $\mathrm{s}$ - e. the thing with sticks. windows for wind and doors for in and out and through. move in. and out and through. now slow to read the sticks: firesticks: dear diary: it'll be a great day when the army holds a bake sale to buy a bomb and today we sang the boys sick with sappho's song to an army wife in sadris. c. 500 b.c.

\author{
some say a cavalry troop \\ others say an infantry and others still \\ will swear that the swift oars \\ of our sea fleet are the best \\ sight on dark earth but I say \\ that whomever one loves is
}


9.

virginia woolf. 1882-1941. 59. suicide: if you insist upon fighting to protect me, or your country, let it be understood, as woman, I have no country.

vietnam. 1969. women in tiger cages. can't stand. can't sit. can't lie. can only squat. became paralysed or dead. beaten unconscious, daily, for singing in their cells. singing songs of liberation. sweet harmony.

firerhymes. fine white lines. lights out. good night, my little children. $80 \%$ of the world's refugees. those who flee from invasion, persecution, or political danger. to be raped. beaten. starved. $70 \%$ of the world's poor. those who lack the means of comfortable subsistence. women. with her little children. feeling insane. clinging to the truth of her own. rocking. singing. still. 
42 . Tessera

10.

dear diary: this is my standpoint. still.

as woman: orifice. clitoris. minora. labia majora.

as poet: blood. breasts. bones.

empowered. firepowered. because I remembered to forget. them. because I remembered to remember us. women: we are. our children are. our houses are. still. imagine that. 